\title{
HUBUNGAN TINGKAT PARTISIPASI LAKI-LAKI DENGAN TINGKAT KEBERDAYAAN EKONOMI PEREMPUAN
}

\author{
The Correlation between Level of Men's Participation with Level of Women's Economic \\ Empowerment
}

\author{
Fahmi Taufiqurrahman ${ }^{1)}$, Titik Sumarti ${ }^{1)}$, Sriwulan Ferindian Falatehan ${ }^{1)}$ \\ ${ }^{1)}$ Departemen Sains Komunikasi dan Pengembangan Masyarakat, Fakultas Ekologi Manusia, \\ Institut Pertanian Bogor, Darmaga Bogor 16680, Indonesia \\ E-mail: taufiqurrahman.df@gmail.com; titik_sumarti@apps.ipb.ac.id; sriwulanferindian@apps.ipb.ac.id
}

\begin{abstract}
World Bank Survey shows that 42,8\% of formal SMEs are owned by women and 43\% of formal SMEs in Indonesia also belong to women with a contribution of 9,1\% to Indonesia's GDP in 2013. Looking at the facts, the improvement of women's economic empowerment becomes important in order to strengthen women's bargaining position in the public sector. Although the program is aimed for women, in practice required the participation of men in supporting women's economic empowerment in order to run balanced development. The purposes of this research are: (1) to identify factors affecting the level of men's participation in supporting the economic activities of women, (2) to analyze the level of men's participation, (3) to analyze the correlation between factors affecting the level of men's participation with the level of men's participation, (4) to analyze the economic empowerment level of women, (5) to analyze the correlation between the level of men's participation with the economic empowerment level of women. The method used in this research is a survey method using a questionnaire to 35 respondents who are husbands of women Kharisma cooperative members who have business. The results from this research shows: (1) the factors that affecting men's participation are type of work, the income level, the education level, and the age of marriage, (2) the level of men's participation at medium level (tokenism), (3) there isn't significant correlation between factors that affecting level of participation with the level of men's participation, (4) the level of women's economic empowerment at the high level and, (5) there is a significant correlation between the level of men's participation with the level of women's economic empowerment.
\end{abstract}

Keywords : Gender, participation, women's empowerment

\begin{abstract}
ABSTRAK
Survei yang dilakukan oleh Bank Dunia menunjukan sebanyak 42,8\% UKM formal dimiliki oleh perempuan dan sebanyak $43 \%$ UKM formal di Indonesia juga milik perempuan dengan kontribusi sebesar $9,1 \%$ terhadap PDB Indonesia pada tahun 2013. Melihat fakta tersebut, peningkatan pemberdayaan ekonomi perempuan menjadi penting demi memperkuat bargaining position perempuan di sektor publik. Meskipun ditujukan untuk perempuan, dalam pelaksanaannya dibutuhkan partisipasi laki-laki dalam mendukung keberdayaan ekonomi perempuan agar pembangunan berjalan seimbang. Penelitian ini bertujuan untuk: (1) mengidentifikasi faktor-faktor yang mempengaruhi tingkat partisipasi laki-laki, (2) mengidentifikasi tingkat partisipasi laki-laki, (3) menganalisis hubungan antara faktor-faktor yang mempengaruhi partisipasi laki-laki dengan tingkat partisipasi laki-laki, (4) mengidentifikasi tingkat keberdayaan ekonomi perempuan, (5) menganalisis hubungan antara tingkat partisipasi laki-laki dengan tingkat keberdayaan ekonomi perempuan. Metode yang digunakan dalam penelitian ini adalah metode survei dengan menggunakan kuesioner kepada 35 responden yang merupakan suami dari perempuan anggota koperasi Kharisma yang memiliki usaha. Hasil penelitian ini menunjukkan (1) faktor-faktor yang mempengaruhi tingkat partisipasi laki-laki antara lain umur, jenis pekerjaan, tingkat pendapatan, tingkat pendidikan, dan lama perkawinan, (2) tingkat partisipasi laki-laki di Desa Sudajaya Girang termasuk ke dalam tingkat partisipasi sedang (tokenisme), (3) terdapat hubungan yang tidak signifikan antara faktorfaktor yang mempengaruhi partisipasi dengan tingkat partisipasi laki-laki, (4) tingkat keberdayaan ekonomi perempuan anggota koperasi tergolong tinggi, dan (5) terdapat hubungan yang signifikan antara tingkat partisipasi laki-laki dengan tingkat keberdayaan ekonomi perempuan.
\end{abstract}

Kata Kunci : Gender, partisipasi, pemberdayaan perempuan 


\section{PENDAHULUAN}

Kebanyakan studi dan kajian gender selama ini membahas tentang perempuan. Hal ini disebabkan dalam pembangunan, ketidakadilan gender lebih dirasakan oleh kaum perempuan. Banyaknya dominasi laki-laki dalam berbagai peran di pembangunan, menempatkan perempuan dalam posisinya di masyarakat dipandang sebagai warga kelas dua yang menduduki posisi subordinat dan marjinal (Martini 2015) sehingga munculnya suatu hegemoni maskulinitas (hegemonic masculinities) yang menyatakan bahwa pihak laki-laki dan sifat maskulinitasnya yang harus bertanggungjawab atas terjadinya kemiskinan/ketidaksejahteraan dalam pembangunan (Chiuri ${ }^{1}$ 2008). Tetapi tidak dapat dipungkiri bahwa dalam proses pembangunan, keterlibatan dan peran serta laki-laki sangat dibutuhkan. Namun sayangnya, dari berbagai studi mengenai gender, hanya sedikit yang menaruh perhatian pada analisis peran laki-laki, dimana lakilaki ditempatkan diluar kegiatan produksi skala rumah tangga. Padahal perlu mengkaji peran lakilaki dalam kontribusinya meningkatkan ekonomi rumah tangga (Chiuri 2008). Pembangunan, di sisi lain, juga menghasilkan perubahan termasuk didalamnya perubahan peran perempuan yang seharusnya juga membawa konsekuensi perubahan peran pada laki-laki. Jika laki-laki sebagai bagian dari masyarakat tidak ikut berubah, maka akan menimbulkan permasalahan. Kondisi yang sering diistilahkan sebagai peran ganda atau multi peran ini, tanpa melibatkan peran laki-laki untuk keseimbangan, cenderung akan menimbulkan berbagai permasalahan dan merupakan konflik bagi perempuan itu sendiri (Saskara et. al. 2012).

Salah satu program pemberdayaan perempuan yang sudah banyak diterapkan adalah koperasi wanita. Dinamakan koperasi wanita-yang selanjutnya akan disebut koperasi perempuan-karena bentuk koperasi ini memiliki struktur kepengurusan dan keanggotaan yang semuanya perempuan. Koperasi perempuan sebenarnya merupakan organisasi yang sudah tidak asing lagi di Indonesia, karena koperasi ini sudah menjadi bagian hidup perempuan sejak zaman kebangkitan Indonesia di tahun 1930an (Agusni 2007). Koperasi terbentuk atas dasar

\footnotetext{
1 Penelitian yang dilakukan oleh Wanjiku Chiuri terkait maskulinitas di Afrika dalam jurnalnya yang berjudul Men's Role in Persistent Rural Poverty: Lessons From Kenya. Studinya menerangkan bahwa “... Africans and in particular African
}

kebutuhan dan kepentingan bersama. Oleh karena itu keberadaan koperasi yang dikelola perempuan terbentuk sebagai wadah bagi para anggotanya untuk mendapatkan akses informasi dan kemudahankemudahan lain dalam rangka menjalankan usahanya. Secara statistik Indonesia tidak menerapkan data usaha kecil menengah (UKM) secara terpilah jenis kelamin, namun survei yang dilakukan IFC (2016) menunjukan bahwa sebesar $43 \%$ dari total UKM formal di Indonesia dimiliki oleh perempuan.

Koperasi perempuan yang dinilai telah berhasil dalam menjalankan perannya memberdayakan perempuan melalui usaha pokok simpan pinjamnya, salah satunya adalah Koperasi Kharisma yang terletak di Desa Sudajaya Girang, Kecamatan Sukabumi, Kabupaten Sukabumi. Koperasi ini dibentuk atas dasar kebutuhan ibu-ibu rumah tangga di Desa Sudajaya Girang untuk melakukan suatu usaha perbaikan ekonomi rumah tangga mereka. Berdiri pada tahun 2004 dan Koperasi Kharisma kini sudah berbadan hukum sejak tahun 2009 berdasarkan BADAN HUKUM No. 15/BH/XIII$15 / 11 / 2009$. Jumlah anggota dari koperasi ini sebanyak 164 orang. Meskipun berlabel "koperasi perempuan", Koperasi Kharisma tidak menutup kesempatan bagi laki-laki untuk menjadi anggota. Sekitar 15 orang laki-laki menjadi anggota koperasi ini. Namun memang dalam struktur kepengurusan hanya dikhususkan bagi perempuan saja. Dikatakan berhasil, karena nilai aset Koperasi Kharisma mencapai 1,3 milyar rupiah. Melihat angka ini, sebenarnya sudah cukup menggambarkan bahwa perempuan dapat berperan dan mengambil keputusan untuk kepentingan bersama. Namun, sesuai dengan pernyataan Agusni (2007), keikutsertaan perempuan sebagai anggota koperasi belum berarti perempuan berperan serta atau ikut mengambil keputusan.

Mendukung hal ini, partisipasi laki-laki, dalam hal ini suami dari anggota koperasi perempuan juga penting untuk diperhatikan. Sesuai dengan yang ditulis dalam buku Peningkatan Produktifitas Ekonomi Perempuan (PEPP) yang diterbitkan oleh Kementerian Pemberdayaan Perempuan dan Perlindungan Anak (KPP-PA 2012), sebagai berikut:

leaders, who are largely men, have contributed significantly to the continent's crises. In one sense we can say that hegemonic masculinities are responsible for perpetuating poverty especially in the rural areas ..." 


\begin{abstract}
“... program pemberdayaan perempuan harus memperhatikan pula keterlibatan peran keluarga dan atau suami dari pihak perempuan yang menjadi kelompok sasaran. Pihak keluarga dan suami tersebut diharapkan dapat memberikan dukungan kepada isteri/anggota keluarganya yang menjadi kelompok sasaran program pemberdayaan, baik dalam wujud pemberian motivasi dan kesempatan untuk melakukan usaha yang menghasilkan secara ekonomi, dimana hal ini mungkin merupakan sesuatu yang relatif baru atau bahkan tabu di kalangan kehidupan komunitas tertentu."
\end{abstract}

Berdasarkan hubungan antara partisipasi laki-laki dan keberdayaan ekonomi perempuan tersebut, maka yang menjadi pertanyaan utama dari penelitian ini, yaitu: apakah terdapat hubungan yang nyata antara tingkat partisipasi laki-laki dalam mendukung aktivitas ekonomi perempuan dengan tingkat keberdayaan ekonomi perempuan anggota Koperasi Kharisma di Desa Sudajaya Girang, Kecamatan Sukabumi, Kabupaten Sukabumi?

Berdasarkan permasalahan tersebut, maka tujuan dari penelitian adalah: (1) mengidentifikasi faktorfaktor yang mempengaruhi partisipasi laki-laki dalam mendukung keberdayaan ekonomi perempuan anggota Koperasi Kharisma, (2) menganalisis tingkat partisipasi laki-laki dalam mendukung aktivitas ekonomi perempuan anggota Koperasi Kharisma, (3) menganalisis hubungan antara faktorfaktor yang mempengaruhi tingkat partisipasi lakilaki dengan tingkat partisipasi laki-laki dalam mendukung aktivitas ekonomi perempuan anggota Koperasi Kharisma, (4) menganalisis tingkat keberdayaan ekonomi perempuan anggota Koperasi Kharisma, (5) menganalisis hubungan antara tingkat partisipasi laki-laki dalam mendukung aktivitas ekonomi perempuan dengan tingkat keberdayaan ekonomi perempuan anggota Koperasi Kharisma.

\section{PENDEKATAN TEORITIS}

\section{Gender}

Gender mengacu pada perbedaan laki-laki dan perempuan dalam peran, perilaku, kegiatan serta atribut yang dikonstruksikan secara sosial (KPP-PA 2013). Utomo et al. (2015) menyatakan bahwa gender adalah aspek majemuk atau kompleks yang merupakan bagian dari kondisi sosial, budaya, ekonomi, dan politik masyarakat. Konsep gender tidak lepas dari peran dan kedudukan antara laki-laki dan perempuan di dalam masyarakat. Utomo et al.
(2015) mendefinisikan perbedaan peran gender sebagai pembagian tanggungjawab dan kerja antara laki-laki dan perempuan. Peran merupakan perilaku individu dalam struktur sosial, dan merupakan aspek dinamis dari kedudukan, yang akhirnya akan memberikan fasilitas tertentu sesuai dengan peranan (role) tersebut. Posisi mengindikasikan status sosial individu di masyarakat. Dengan kata lain, kedudukan memberikan seseorang sebuah peran sebagai pola interaksi dalam bersosialisasi (bermasyarakat). Seseorang dinilai telah berperan, bilamana ia telah melakukan hak dan kewajiban sesuai dengan statusnya (Elizabeth 2007).

\section{Partisipasi}

Menurut Nasdian (2014), partisipasi adalah proses aktif, inisiatif diambil oleh warga komunitas sendiri, dibimbing oleh cara aktif berfikir mereka sendiri, dengan menggunakan sarana dan proses (lembaga dan mekanisme) dimana mereka dapat menegaskan kontrol secara efektif. Partisipasi tersebut dapat dikategorikan: Pertama, warga komunitas dilibatkan dalam tindakan yang telah dipikirkan atau dirancang oleh orang lain dan dikontrol oleh orang lain. Kedua, partisipasi merupakan proses pembentukan kekuatan untuk keluar dari masalah mereka sendiri.

Advianty dan Handayeni (2013) serta Duadji (2013) dalam jurnalnya, meneliti partisipasi masyarakat dengan merujuk pada ladder of participation yang dikemukakan Arnstein (1969). Menurut konsep ini terdapat tiga derajat partisipasi yang kemudian diperinci kedalam delapan tahapan anak tangga partisipasi. Nasdian (2014) dalam bukunya menjelaskan kedelapan anak tangga tersebut, yaitu:

1. Manipulation (manipulasi), dimana partisipasi hanya sebagai formalitas semata dan masyarakat diikutsertakan sebagai "stampel karet" dalam badan penasihat.

2. Therapy (terapi), dimana ketidakberdayaan masyarakat dianggap sebagai penyakit sehingga keterlibatan masyarakat hanya bertujuan untuk menghilangkan "luka"-nya saja dan bukan menemukan penyebab "luka"-nya,

3. Informing (menginformasikan), yaitu pemberian informasi kepada masyarakat akan hak, tanggungjawab, dan pilihan mereka. Namun seringkali pemberian informasi ini bersifat satu arah sehingga masyarakat tidak memiliki kesempatan dan kekuatan untuk melakukan negosiasi. Pemberian informasi ini biasanya melalui media seperti pamflet atau poster. 
4. Consultation (konsultasi), merupakan bentuk partisipasi semu dimana masyarakat mulai diminta pendapatnya melalui forum jajak pendapat dan pertemuan warga. Tetapi pemegang kekuasaan tetap yang mengambil keputusan, karena partisipasi ini hanya diukur dari frekuensi kehadiran masyarakat dalam pertemuan, seberapa banyak brosur yang dibawa pulang, dan seberapa banyak kuesioner yang dijawab.

5. Placation (menenangkan), dimana masyarakat sudah memiliki beberapa pengaruh dengan memberi masukan dan mengusulkan rencana, tetapi keputusan tetap dipegang oleh pemangku kekuasaan.

6. Partnership (kemitraan), dimana kekuasaan disalurkan melalui negosiasi antara pemegang kekuasaan dengan masyarakat. Mereka sepakat untuk sama-sama memikul tanggungjawab dalam perencanaan dan pengambilan keputusan.

\section{Delegated power (kekuasaan yang} didelegasikan), pada tingkatan ini masyarakat menduduki mayoritas kursi sehingga memiliki kekuasaan dalam menentukan suatu keputusan. Perbedaan-perbedaan dengan pemegang kekuasaan diatasi dengan melakukan tawarmenawar.

8. Citizen control (kontrol warga negara), yang merupakan tingkatan partisipasi terakhir dimana masyarakat menginginkan adanya jaminan bahwa kewenangan untuk mengatur program dan kelembagaan sepenuhnya diberikan kepada mereka.

Delapan tangga partisipasi Arnstein tersebut kemudian dikelompokkan ke dalam tiga derajat. Derajat pertama merupakan derajat yang terendah dan disebut dengan nonpartisipan. Aktivitas partisipasi yang terjadi di daerah ini sebenarnya merupakan distorsi partisipasi. Tujuan yang sebenarnya tidak untuk mendukung rakyat berpartisipasi dalam pembuatan dan implementasi keputusan, tetapi lebih sekedar tujuan penguasa untuk mendidik dan menyenangkan partisipan. Derajat ini melingkupi anak tangga manipulasi dan terapi. Derajat kedua adalah derajat yang menunjukkan adanya tanda partisipasi (tokenism) dimana keterlibatan warga sudah lebih tinggi dari derajad pertama. Derajat kedua ini melingkupi anak tangga pemberian informasi, konsultasi dan penentraman (placation). Sudah terjadi aktivitas dialog dengan publik yang berarti warga memiliki hak untuk didengar pendapatnya meskipun tidak terlibat secara langsung dalam pengambilan keputusan. Pemberian informasi menandakan adanya komunikasi satu arah dari pihak pengendali otoritas (penguasa) kepada publik melalui penyebaran pamflet, pengumuman dan laporan tahunan. Konsultasi menunjukkan dialog dua arah melalui survey sikap, temu warga, dan dengar pendapat publik. Sementara penentraman melibatkan aktivitas yang lebih dalam dengan mengajak masyarakat terlibat dalam komite pembuatan kebijakan meskipun penguasa tetap sebagai pemegang kendali utama pembuat dan penentu kebijakan. Derajat ketiga adalah kendali warga yang memberikan peluang keterlibatan lebih kuat dalam pembuatan kebijakan. Warga ambil bagian secara langsung baik dalam pengambilan keputusan maupun pelayanan publik. Derajat ini mencerminkan adanya redistribusi kekuasaan dari pemerintah kepada masyarakat. Terdapat 3 (tiga) anak tangga dalam derajat ini, yaitu: kemitraan, kuasa yang didelegasi dan kendali warga.

\section{Pemberdayaan}

Pemberdayaan (Nasdian 2014) secara konseptual membahas bagaimana iindividu, kelompok, ataupun komunitas berusaha mengontrol kehidupan mereka sendiri dan mengusahakan untuk membentuk masa depan sesuai dengan keinginan mereka. Pemberdayaan (empowerment) juga ditujukan untuk membantu "klien" memperoleh daya (kuasa) untuk mengambil keputusan dan menentukan tindakan yang akan ia lakukan yang terkait dengan diri mereka, termasuk mengurangi efek hambatan pribadi dan sosial dalam melakukan tindakan. Pemberdayaan (empowerment) merupakan serangkaian upaya untuk meningkatkan kemampuan dan memperluas akses terhadap suatu kondisi untuk mendorong kemandirian yang berkelanjutan (tanggap dan kritis terhadap perubahan) serta mampu berperan aktif dalam menentukan nasibnya sendiri, melalui penciptaan peluang yang seluas-luasnya agar mampu berpartisipasi (Sumodiningrat 1999 dalam Elizabeth 2007). Elizabeth (2007) mendefiniskan pemberdayaan (empowerment) perempuan sebagai upaya penguatan terhadap ketidakberdayaan mereka agar mampu menolong diri sendiri, mandiri, serta mengembangkan semangat self-reliance-nya.

Handayani (2002) menambahkan bahwa dalam analisis gender juga biasanya menggunakan pendekatan analisis Longwe. March et al. (1999) menjelaskan lima dimensi pemberdayaan dalam alat analisis ini, yaitu: 


\section{Dimensi Kesejahteraan}

Dimensi ini merupakan tingkat kesejahteraan material yang diukur dari tercukupinya kebutuhan dasar seperti makanan, penghasilan, perumahan, dan kesehatan yang harus dinikmati oleh perempuan dan laki-laki. Dengan demikian kesenjangan gender ditingkat kesejahteraan ini diukur melalui perbedaan tingkat kesejahteraan perempuan dan laki-laki sebagai kelompok untuk masing-masing kebutuhan dasarnya. Pemberdayaan tidak dapat terjadi dengan sendirinya di tingkat ini, melainkan harus dikaitkan dengan peningkatan akses terhadap sumberdaya yang merupakan dimensi tingkat kedua. Level ini merupakan tingkatan nihil dari pemberdayaan perempuan. Padahal upaya untuk memperbaiki kesejahteraan perempuan diperlukan keterlibatan perempuan dalam proses empowerment dan pada tingkat pemerataan yang lebih tinggi.

\section{Dimensi Akses}

Kesenjangan gender disini terlihat dari adanya perbedaan akses antara laki-laki dan perempuan terhadap sumberdaya. Lebih rendahnya akses mereka terhadap sumberdaya menyebabkan produktivitas perempuan cenderung lebih rendah dari laki-laki. Selain itu dalam banyak komunitas, perempuan diberi tanggung jawab melaksanakan hampir semua pekerjaan domestik sehingga tidak mempunyai cukup waktu untuk mengurusi dan meningkatkan kemampuan dirinya. Pembangunan perempuan tidak cukup hanya pada pemerataan akses karena kurangnya akses perempuan bukan saja merupakan isu gender, tetapi akibat dari diskriminasi gender. Oleh karena itu, akar penyebab kesenjangan akses atas sumberdaya adalah diskriminasi sistemik yang harus diatasi melalui penyadaran.

\section{Dimensi Kesadaran Kritis}

Kesenjangan gender di tingkat ini disebabkan adanya anggapan bahwa posisi sosial-ekonomi perempuan yang lebih rendah dari laki-laki dan pembagian kerja gender tradisional adalah bagian dari tatanan abadi. Pemberdayaan di tingkat ini berarti menumbuhkan sikap kritis dan penolakan terhadap cara pandang atas: bahwa subordinasi terhadap perempuan bukanlah pengaturan alamiah, tetapi hasil diskriminatif dari tatanan sosial yang berlaku. Keyakinan bahwa kesetaraan gender adalah bagian dari tujuan perubahan merupakan inti dari kesadaran gender dan merupakan elemen ideologis dalam proses pemberdayaan yang menjadi landasan konseptual bagi perubahan ke arah kesetaraan.

\section{Dimensi Partisipasi}

Partisipasi aktif perempuan diartikan bahwa pemerataan partisipasi perempuan dalam proses penetapan keputusan yaitu partisipasi dalam proses perencanaan penentuan kebijakan dan administrasi. Aspek ini sangat penting pada proyek pembangunan. Disini partisipasi berarti keterlibatan atau keikutsertaan aktif sejak dalam penetapan kebutuhan, formulasi proyek, implementasi, dan monitoring serta evaluasi. Partisipasi dapat dibedakan menjadi partisipasi kuantitatif dan partisipasi kualitatif. Kesenjangan partisipasi perempuan mudah diidentifikasi, misalnya dari partisipasi di lembaga legislatif, eksekutif, organisasi, politik, dan massa. Namun partisipasi secara umum dapat dilihat dari adanya peran serta setara antara laki-laki dan perempuan dalam pengambilan keputusan, baik di tingkat keluarga, komunitas, masyarakat maupun negara. Di tingkat program, ini berarti dilibatkannya perempuan dan laki-laki secara setara dalam identifikasi masalah, perencanaan, pengelolaan, implementasi dan monitoring evaluasi. Meningkatnya peran serta perempuan merupakan hasil dari pemberdayaan sekaligus sumbangan penting bagi pemberdayaan yang lebih besar.

\section{Dimensi Kuasa/Kontrol}

Kesenjangan gender di tingkat ini terlihat dari adanya hubungan kuasa yang timpang antara lakilaki dan perempuan. Ini bisa terjadi di tingkat rumah tangga, komunitas, dan tingkatan yang lebih luas lagi. Kesetaraan dalam kuasa berarti adanya kuasa yang seimbang antara laki-laki dan perempuan, satu tidak mendominasi atau berada dalam posisi dominan atas lainnnya. Artinya perempuan mempunyai kekuasaan sebagaimana juga laki-laki, untuk mengubah kondisi posisi, masa depan diri dan komunitasnya. Kesetaraan dalam kuasa merupakan prasyarat bagi terwujudnya kesetaraan gender dan keberdayaan dalam masyarakat yang sejahtera. 


\section{KERANGKA PEMIKIRAN}

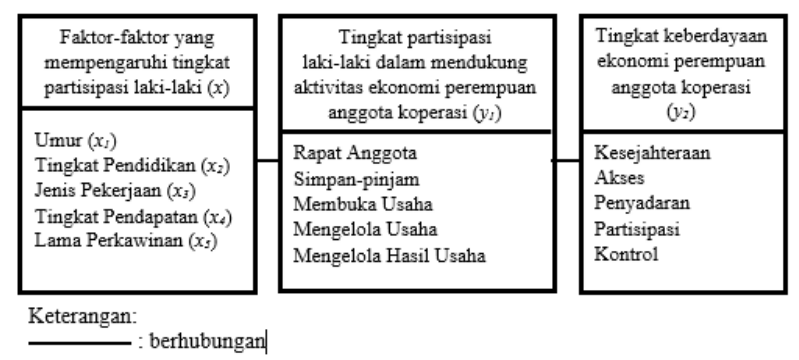

Gambar 1 Kerangka Pemikiran Hubungan antara Tingkat Partisipasi Laki-laki dengan Tingkat Keberdayaan Ekonomi Perempuan

\section{METODE PENELITIAN}

Pendekatan yang digunakan dalam penelitian ini yaitu pendekatan kuantitatif dengan metode survei kepada 35 responden, serta diperkuat oleh pendekatan kualitatif. Penelitian ini dilakukan di Koperasi Perempuan Kharisma, Desa Sudajaya Girang, Kecamatan Sukabumi, Kabupaten Sukabumi, dilaksanakan dalam jangka waktu enam bulan, terhitung mulai bulan Januari 2017 sampai dengan Juni 2017.

Penelitian ini memiliki dua jenis data yang diolah dan dianalisis, yaitu data kuantitatif dan data kualitatif. Data kuantitatif diolah menggunakan aplikasi Microsoft Excel 2016 dan IBM SPSS Statistics 16.0 for Windows. Data dianalisis dengan menggunakan tabel frekuensi dan tabulasi silang untuk melihat data awal responden untuk masingmasing variabel secara tunggal menggunakan aplikasi Microsoft Excel 2016. IBM SPSS Statistics 16.0 for Windows digunakan untuk menganalisis signifikansi hubungan antar dua variabel yang berskala ordinal dengan menggunakan uji korelasi Rank Spearman, dan Chi-square untuk data yang berskala nominal. Uji korelasi Rank Spearman dalam penelitian ini digunakan untuk manganalisis hubungan antara faktor-faktor yang mempengaruhi tingkat partisipasi laki-laki (umur, tingkat pendapatan, tingkat pendidikan, dan lama perkawinan) dengan tingkat partisipasi laki-laki dalam mendukung aktivitas ekonomi perempuan, serta untuk menganalisis tingkat partisipasi laki-laki dalam mendukung aktivitas ekonomi perempuan dengan tingkat keberdayaan ekonomi perempuan anggota koperasi. Sementara itu, uji korelasi Chisquare digunakan untuk menganalisis hubungan antara faktor jenis pekerjaan dengan tingkat partisipasi laki-laki. Uji korelasi dilakukan dengan dua arah (two tailed) atau hanya menguji ada tidaknya hubungan diantara kedua variabel yang diuji serta menentukan kuat atau lemahnya hubungan tersebut. Data kualitatif dianalisis melalui tiga tahap yaitu reduksi data, penyajian data, dan verifikasi. Pertama ialah proses reduksi data dimulai dari proses pemilihan dan penyederhanaan data hasil wawancara mendalam berupa catatan lapangan, observasi, dan studi dokumen yang direduksi dalam tulisan tematik. Tujuan dari reduksi data ini ialah untuk mempertajam, menggolongkan, mengarahkan, dan membuang data yang tidak perlu. Kedua ialah penyajian data dengan menyusun segala informasi dan data yang diperoleh menjadi serangkaian katakata yang mudah dibaca ke dalam sebuah laporan berupa kutipan atau tipologi. Verifikasi adalah langkah terakhir yang merupakan penarikan kesimpulan dari hasil yang telah diolah untuk mendukung data kuantitatif.

\section{HASIL DAN PEMBAHASAN}

\section{Faktor-faktor yang Mempengaruhi Tingkat Partisipasi Laki-laki}

Berdasarkan kerangka pemikiran dalam penelitian ini (Gambar 1) terdapat faktor-faktor yang dapat mempengaruhi tingkat partisipasi laki-laki. Faktorfaktor tersebut antara lain umur, tingkat pendidikan, pekerjaan, tingkat pendapatan, dan lamanya perkawinan.

Hasil penelitian menunjukan bahwa sebanyak $60 \%$ responden berada di kelompok umur dewasa menengah (31-50 tahun). Selanjutnya, sebanyak $48.6 \%$ responden berada pada tingkat pendidikan sedang, yaitu di jenjang tamat SMP dan SMA. Kemudian sebanyak $48.6 \%$ pekerjaan responden adalah berdagang. Hal ini mendukung keberadaan Koperasi Kharisma yang berfungsi sebagai penyedia modal bagi anggotanya untuk mengembangkan usaha mereka. Selanjutnya, sebanyak $48.6 \%$ responden berada pada tingkat pendapatan rendah, yaitu dibawah Rp. 2.000.000. Hal ini dikarenakan sebagian responden pun banyak yang bekerja sebagai buruh tani maupun buruh bangunan yang pendapatannya tidak menentu dan tidak rutin didapat setiap bulan. Kemudian, sebanyak $45.7 \%$ responden berada pada kategori lama perkawinan antara 10 sampai 20 tahun. Namun terdapat juga beberapa 
responden yang termasuk ke dalam kategori lama perkawinan $<10$ tahun dikarenakan baru saja menikah dan ada pula yang menikah lagi karena istri pertama responden telah meninggal dunia.

\section{Analisis Tingkat Partisipasi Laki-laki dalam Mendukung Aktivitas Ekonomi Perempuan}

Partisipasi laki-laki dalam penelitian ini diukur berdasarkan keterlibatan responden terhadap aktivitas ekonomi istrinya, antara lain rapat anggota, simpan-pinjam, membuka usaha, mengelola usaha, dan mengelola hasil usaha.

Pada kegiatan rapat anggota, sebanyak 57.1\% responden berada pada tingkat partisipasi sedang. Hal ini didukung oleh sebanyak $40 \%$ responden menyatakan "Mengizinkan untuk menghadiri rapat, tanpa syarat" dan $17.1 \%$ menyatakan "Mengizinkan setelah ada pemberitahuan sebelumnya". Kedua pernyataan tersebut termasuk kedalam tingkat partisipasi sedang. Pemberian izin pada perempuan yang dilakukan oleh responden dikarenakan hampir seluruh responden mempercayai bahwa kegiatan yang diadakan oleh Koperasi Kharisma merupakan kegiatan yang positif dan bermanfaat, sehingga tidak ada alasan bagi responden untuk tidak mengizinkan istrinya yang merupakan anggota koperasi untuk mengikuti kegiatan rapat. Pernyataan ini sesuai dengan salah satu penuturan responden berikut:

"Kalau ada kegiatan koperasi mah a, udah pasti saya ijinin. Soalnya kan itu kegiatan positif, sambil silaturahmi juga ke tetanggatetangga sekitar yang ikutan koperasi. Apalagi rapat anggota a, jangan sampai si ibu ketinggalan informasi. Lagian kasian juga si ibu kalau di rumah terus, sekali-sekali biar bergaul juga sama ibu-ibu lainnya" Bapak SPD, 54 tahun.

Kemudian, pada kegiatan simpan-pinjam, sebanyak $60 \%$ tingkat partisipasi responden berada pada tingkat sedang. Hasil pengukuran kuesioner menggambarkan bahwa dalam melakukan kegiatan simpan-pinjam ke koperasi, adanya diskusi terlebih dahulu antara responden dengan istrinya untuk menentukan besaran nominal uang yang akan dipinjam. Dalam kasus ini, besaran jumlah pinjaman yang diajukan ke koperasi tidak hanya sejumlah uang yang dibutuhkan untuk kepentingan kegiatan istri saja, tetapi ada juga kebutuhan suami didalamnya. Hal ini dikarenakan hampir di seluruh rumah tangga responden tidak membagi secara tegas pendapatan suami dan pendapatan istri, sehingga seluruh pendapatan menjadi satu yaitu pendapatan rumah tangga, sehingga dalam meminjam pun besaran yang akan dipinjam harus mencakup kebutuhan rumah tangga, sesuai dengan pernyataan yang diutarakan oleh salah satu responden berikut,

\section{"Oh, harus ada diskusi dulu dong, a. Apalagi masalah uang, kan ga boleh sembarangan pinjam. Kalau nanti ngga sanggup bayar, kan kita juga yang repot," Bapak JMR, 45 tahun.}

Kemudian, pada kegiatan membuka usaha, sebanyak $74.3 \%$ responden sudah berpartisipasi dalam memberikan kontrol penuh terhadap perempuan untuk merencanakan usahanya. Hasil tersebut menggambarkan bahwa dalam menentukan dan merencanakan jenis usaha, istri responden memiliki kendali penuh dalam perencanaan usahanya. Jenis usaha yang biasanya dilakukan tidak jauh dari barang dagangan seperti warung sembako, jajanan anakanak, gorengan, maupun kedai mie instan. Dalam hal ini, peran suami adalah mempercayai semua keputusan perencanaan usaha kepada istrinya.

Selanjutnya, pada kegiatan mengelola usaha, sebanyak $42.9 \%$ responden berada pada tingkat rendah. Hasil ini menggambarkan bahwa mayoritas responden tidak ikut terlibat dalam kegiatan mengelola usaha yang dilakukan oleh istri mereka. Alasan responden tidak membantu atau jika membantu, hanya saat responden memiliki waktu senggang saja. Hal ini dikarenakan responden bekerja ditempat yang relatif jauh dari rumah mereka. Waktu kerja responden pun dari rentang pagi hingga sore hari, sekitar pukul 16.00-18.00 WIB responden baru pulang ke rumah. Selain itu, responden pun kurang mengetahui kebutuhan usaha yang diperlukan oleh istrinya sehingga responden cukup memberi uang hasil kerjanya saja kepada istrinya. Hal ini sesuai dengan pernyataan salah satu responden berikut,

"Kalau urusan usaha si ibu mah, yaa biar si ibu
aja a yang ngerjain. Kan lumayan buat bantu-
bantu cari uang. Sayajarang bantu soalnya kan
kerja juga. Jadi paling kalau lagi senggang aja,
sabtu-minggu mah bisa bantuin,” Bapak DN,
35 tahun.

Kemudian, pada kegiatan mengelola hasil usaha, sebanyak $88.6 \%$ responden berada pada tingkat partisipasi tinggi. Hasil tersebut menggambarkan bahwa dalam pengelolaan uang hasil usaha ekonomi 
istri, responden menyerahkan kontrol penuh agar keputusan alokasinya diatur dan ditentukan oleh istrinya. Lebih dari itu, sebagian besar responden justru menyerahkan keputusan alokasi pendapatan rumah tangga, termasuk pendapatan kerja responden, untuk diatur oleh istrinya. Hal ini dikarenakan menurut responden, perempuan lebih handal dalam mengatur keuangan rumah tangga. Sesuai dengan pernyataan salah satu responden berikut,

\section{"Kalau masalah keuangan mah istri aja yang atur. Perempuan kan lebih jago ngatur uang, dek. Kalau uang di suami semua, malah habis buat jajan atau dibeliin yang macem-macem. Makanya saya mah suka ngasih aja langsung ke istri kalau dapat uang. Takut keburu habis, " Bapak NJM, 45 tahun}

Berdasarkan hasil pengukuran tingkat partisipasi laki-laki pada tiap-tiap aktivitas ekonomi perempuan sebelumnya, kemudian diambil kesimpulan bahwa tingkat partisipasi laki-laki dalam mendukung aktivitas ekonomi perempuan secara keseluruhan, sebanyak $60 \%$. Tingkatan ini menurut ladder of participation Arnstein tergolong dalam tokenisme. Dalam bukunya "Pengembangan Masyarakat", Nasdian (2014) menerangkan bahwa pada tingkat tokenisme sudah menunjukkan adanya tanda partisipasi. Artinya, laki-laki di Desa Sudajaya Girang tidak terlalu terlibat dalam kegiatan ekonomi istrinya. Adapun dukungan yang diberikan laki-laki dalam kasus ini berupa pemberian izin, namun dengan tetap menekankan bahwa perempuan tidak boleh melupakan tugas mereka di rumah terlebih dahulu. Wawancara lebih lanjut juga dilakukan kepada pihak istri responden dan sebagian besar menyatakan bahwa mereka sudah memiliki kesadaran sendiri untuk menyelesaikan pekerjaan rumah terlebih dahulu sebelum melakukan aktivitas lain.

\section{Hubungan Antara Faktor-faktor yang Mempengaruhi Tingkat Partisipasi Laki-laki dengan Tingkat Partisipasi Laki-laki dalam Mendukung Aktivitas Ekonomi Perempuan}

Hasil uji korelasi menunjukkan bahwa tidak terdapatnya hubungan yang signifikan antara faktorfaktor yang mempengaruhi partisipasi laki-laki, yaitu umur, tingkat pendidikan, jenis pekerjaan, tingkat pendapatan, dan lama perkawinan, dengan tingkat partisipasi laki-laki dalam mendukung aktivitas ekonomi perempuan dengan nilai signifikansi masing-masing $0.932,0.117,0.085,0.737,0.800$. Nilai tersebut lebih besar dari taraf nyata $5 \%(\mathrm{p}>$ 0.05 ) sehingga menunjukkan hubungan yang tidak signifikan.

Hasil ini diduga karena penggunaan alat analisis yang merujuk pada teori partisipasi Arnstein (1969) tentang ladder of participation kurang tepat. Hal ini dikarenakan, teori ladder of participation Arnstein (1969) lebih tepat digunakan pada level komunitas, sementara unit analisis pada penelitian ini berskala individu. Kemudian dapat disimpulkan pula, bahwa laki-laki dengan tingkat partisipasi tokenisme, apabila dilihat dari faktor-faktor yang mempengaruhi tingkat partisipasi laki-laki, memiliki karakteristik, yaitu umurnya berada pada kategori dewasa menengah, bekerja di sektor perdagangan dengan tingkat pendapatan rendah, memiliki tingkat pendidikan sedang, dan lama perkawinan antara 1020 tahun.

\section{Analisis Tingkat Keberdayaan Ekonomi Perempuan}

Tingkat keberdayaan ekonomi perempuan diukur dalam lima aspek, yaitu kesejahteraan, akses, penyadaran, partisipasi, dan kontrol. Pada aspek kesejahteraan, sebanyak $60 \%$ responden menyatakan kesejahteraan perempuan (istri responden) berada pada kategori tinggi. Hasil ini diperoleh karena sebagian besar responden mengakui bahwa usaha ekonomi istrinya telah mampu menyumbang pendapatan keluarga untuk memenuhi kebutuhan keluarga sehari-hari, antara lain kebutuhan pangan, pakaian, biaya pendidikan anak, perabotan keluarga, serta kebutuhan istri itu sendiri. Namun jika ditinjau satu per satu, melalui wawancara mendalam, ditemukan bahwa sebagian besar pendapatan yang dihasilkan melalui usaha ekonomi istri lebih dialokasikan untuk kebutuhan pribadi istri dan kebutuhan pangan keluarga. Sementara untuk biaya pendidikan anak sebagian besar masih dibayarkan melalui pendapatan suami. Pengahsilan istri hanya untuk menambah uang saku sekolah anak saja. Hal ini sesuai dengan pernyataan salah satu responden berikut,

\footnotetext{
"Kalau buat bayar SPP sih masih tanggungan saya, a. Istri mah paling nambahin uang jajan
} 
anak aja. Tapi biasanya juga anak dibekelin sih dari rumah biar ga banyakjajan," Bapak ADL, 32 tahun.

Kemudian pada aspek akses, sebanyak $65.7 \%$ responden menyatakan akses perempuan terhadap sumberdaya produktif berada pada kategori sedang. Hasil ini diperoleh karena sebagian besar responden mengakui bahwa dalam menjalankan usaha ekonominya, istri telah mampu mengakses beberapa sumberdaya produktif seperti harga pasar, pelatihan, serta pembeli/pelanggan. Sementara untuk akses terhadap kendaraan bermotor dan internet masih banyak yang tidak dapat mengakses. Hal ini sesuai dengan pernyataan salah satu responden berikut,

"Si ibu dulu pernah saya ajarin buat naik motor. Tapi jatoh sekali langsung ngga mau lagi, a. Takut katanya. Yaudah sekarang si ibu kemana-mana paling naik angkot, kalau deket ya jalan," Bapak ASD, 35 tahun.

Selanjutnya pada aspek penyadaran, sebanyak $65.7 \%$ responden menyatakan penyadaran perempuan terhadap peran gender dan peran jenis kelamin berada pada kategori tinggi. Jawaban ini menggambarkan bahwa responden menyadari meskipun istrinya memiliki usaha ekonomi, tetapi tidak melupakan tugasnya di rumah tangga. Dalam kasus ini, istri responden selalu mengutamakan pekerjaan rumah tangga terlebih dahulu sebelum menjalankan usaha ekonominya. Hal ini juga dikarenakan masih terdapat responden yang sama sekali tidak membantu istrinya untuk mengerjakan pekerjaan rumah tangga dikarenakan budaya patriarkhi yang kental serta alasan agama. Berdasarkan fakta tersebut, maka dapat disimpulkan bahwa perempuan dalam hal ini telah menyadari perannya secara gender. Namun laki-laki, dalam kasus ini responden, belum memiliki penyadaran akan peran gendernya dan mengikuti peran yang dibentuk oleh budaya masyarakat setempat yang masih patriarkhi.

Selanjutnya pada aspek partisipasi, sebanyak $71.4 \%$ responden menyatakan partisipasi perempuan dalam perencanaan dan pengambilan keputusan berada pada kategori tinggi. Hasil ini diperoleh karena istri responden sudah terlibat dalam proses perencanaan dan pengambilan keputusan baik terkait usaha ekonominya maupun dalam hal keluarganya. Saat diwawancarai lebih lanjut ditemukan bahwa sebagian besar responden tidak terlalu terlibat dalam perencanaan dan pengambilan keputusan yang dilakukan oleh istrinya dalam kegiatan usaha ekonominya. Namun dalam urusan keluarga, pengambilan keputusan dilakukan oleh responden dan istrinya secara bersama. Hal ini sesuai dengan pernyataan salah satu responden berikut,
"Kalau masalah keluarga memang harus diobrolin bareng-bareng, A. Ngga boleh nentuin sendiri. Namanya rumah tangga bersama, ya kalau ada apa-apa harus diselesaikan bersama juga," Bapak JJN, 33 tahun.

Kemudian pada aspek kontrol, sebanyak $77.1 \%$ responden menyatakan penguasaan perempuan terhadap faktor produksi dan distribusi hasil usahanya berada pada kategori tinggi. Pada kasus ini, suami tidak terlalu memiliki keuasaan dalam artian tidak mengatur pengelolaan faktor produksi dalam kegiatan usaha ekonomi istrinya dikarenakan suami pun sudah memiliki kesibukan dalam pekerjaannya sehari-hari. Namun meskipun demikian, jika istri meminta bantuan kepada suaminya terkait urusan usaha ekonomi, suami bersedia membantu. Hal ini sesuai dengan pernyataan responden berikut,
"Kalau urusan dagangan biar si ibu aja yang mengatur. Soalnya dia yang lebih tau kebutuhannya kan. Tapi biasanya juga saya ikut bantu beli bahan-bahannya. Si ibu kan jualan cat, nah biasanya saya yang ke pasar pesen catnya buat diantar ke rumah," Bapak NJM, 45 tahun.

Kemudian, berdasarkan hasil pengukuran secara keseluruhan menunjukkan bahwa sebanyak 57.1\% responden menyatakan bahwa tingkat keberdayaan ekonomi perempuan berada pada tingkat keberdayaan sedang. Hasil ini menunjukkan bahwa perempuan sudah dapat mengelola usaha ekonominya secara mandiri. Meskipun terdapat keterlibatan laki-laki dalam beberapa kegiatannya, namun sebagian besar keputusan sudah berada di pihak perempuan. Hal ini disebabkan karena lakilaki yang memiliki kesibukan dalam pekerjaannya sehingga urusan usaha ekonomi rumah tangga lebih diserahkan kepada perempuan. Kemampuan perempuan dalam mengelola ekonomi rumah tangganya dan usahanya didapatkan melalui pelatihan-pelatihan yang diselengarakan oleh pihak Koperasi Kharisma yang memang dikhususkan 
untuk perempuan. Dengan mengikuti berbagai pelatihan tersebut, perempuan anggota koperasi mendapatkan berbagai macam keterampilan, antara lain keterampilan dalam berbicara, menyampaikan pendapat baik di masyarakat maupun di keluarga, keterampilan mengelola keuangan keluarga, serta keterampilan membuka dan mengelola usaha. Dengan keterampilan-keterampilan tersebut, perempuan anggota koperasi kini memiliki rasa percaya diri yang lebih dari perempuan yang tidak tergabung dalam koperasi. Hal ini sesuai dengan pernyataan responden berikut,

"Alhamdulillah, A, banyak perubahan dari ibu yang saya liat yah setelah ikut koperasi. Nambah pengetahuan, jadi tau tentang masalah mengatur keuangan, berani bicara, nyampein saran juga biasanya kalau saya lagi ada masalah. Alhamdulillah lah pokoknya. Soalnya koperasi juga kan suka ngadain pelatihan-pelatihan juga," Bapak SFA, 39 tahun.

\section{Hubungan Antara Tingkat Partisipasi Laki-laki dalam Mendukung Aktivitas Ekonomi Perempuan dengan Tingkat Keberdayaan Ekonomi Perempuan}

Hasil uji korelasi rank spearman terhadap hubungan antara tingkat partisipasi laki-laki dengan tingkat keberdayaan ekonomi perempuan memiliki nilai signifikansi 0.007 dengan taraf 0.05 (pengujian dua arah). Nilai tersebut lebih kecil dari taraf nyata $5 \%$ (p $<0.05$ ), sehingga terdapat hubungan yang signifikan antara tingkat partisipasi laki-laki dalam mendukung aktivitas ekonomi perempuan dengan tingkat keberdayaan ekonomi perempuan. Sedangkan nilai koefisien dari hasil uji korelasi tersebut yaitu 0.448 . Jika dilihat dari aturan nilai koefisien uji korelasi, maka nilai tersebut masuk ke dalam kategori korelasi cukup, yaitu $>0.25-0.5$.

Berdasarkan pada penjelasan sebelumnya, diketahui bahwa tingkat keberdayaan ekonomi perempuan diukur pada aspek kesejahteraan, akses, penyadaran, partisipasi, dan kontrol yang berkaitan dengan kegiatan usaha ekonominya. Begitupun dengan tingkat partisipasi laki-laki diukur pada tahapantahapan kegiatan usaha ekonomi yang dilakukan perempuan, mulai dari rapat anggota, simpanpinjam, membuka usaha, mengelola usaha, hingga mengelola hasil usaha. Meskipun masih berada pada derajat tokenisme, namun hasil pengukuran menyatakan bahwa responden, dalam kasus ini suami, mendukung kegiatan usaha ekonomi yang dilakukan oleh istrinya. Mengacu pada realitas di lapang, tingkat keberdayaan ekonomi perempuan memiliki hubungan dengan tingkat partisipasi lakilaki.

\section{SIMPULAN DAN SARAN}

\section{Simpulan}

Berdasarkan hasil penelitian yang telah dikemukakan sebelumnya, dapat diambil beberapa kesimpulan sebagai berikut:

1. Faktor-faktor yang mempengaruhi tingkat partisipasi laki-laki antara lain umur, jenis pekerjaan, tingkat pendapatan, tingkat pendidikan, dan lama perkawinan. Karakteristik laki-laki suami perempuan pelaku usaha adalah kategori umur dewasa menengah, bekerja di sektor perdagangan dengan tingkat pendapatan yang rendah, memiliki tingkat pendidikan sedang, serta lama perkawinan antara 10-20 tahun.

2. Tingkat partisipasi laki-laki dalam mendukung aktivitas ekonomi perempuan responden sebagian besar berada pada tingkat sedang atau derajat tokenisme menurut ladder of participation Arnstein (1969). Hal ini menggambarkan bahwa sudah terdapat tanda partisipasi responden dalam mendukung usaha ekonomi istri. Dukungan yang dimaksud dalam penelitian ini berupa dukungan dan izin suami.

3. Tidak terdapat hubungan yang signifikan antara umur, jenis pekerjaan, tingkat pendapatan, tingkat pendidikan, dan lama perkawinan dengan tingkat partisipasi laki-laki dalam mendukung aktivitas ekonomi perempuan. Hal ini diduga karena kurang tepatnya penggunaan alat analisis yang merujuk pada teori Arnstein (1969) dalam mengukur tingkat partisipasi laki-laki.

4. Tingkat keberdayaan perempuan anggota Koperasi Kharisma di Desa Sudajaya Girang termasuk ke dalam kategori sedang. Artinya perempuan sudah berdaya secara ekonomi.

5. Terdapat hubungan yang signifikan antara tingkat partisipasi laki-laki dalam mendukung aktivitas ekonomi perempuan dengan tingkat keberdayaan ekonomi perempuan anggota koperasi. Hal ini menggambarkan bahwa semakin tinggi tingkat partisipasi laki-laki, maka semakin tinggi tingkat keberdayaan ekonomi perempuan. 


\section{Saran}

Berdasarkan hasil penelitian, maka dapat diusulkan beberapa hal yang dapat dijadikan masukan atau saran, diantaranya sebagai berikut:

1. Perlunya penelitian dan pengkajian lebih lanjut mengenai hubungan antara faktor-faktor yang mempengaruhi partisipasi, tingkat partisipasi laki-laki, dan tingkat keberdayaan ekonomi perempuan.

2. Perlunya pengkajian lebih lanjut mengenai penggunaan alat ukur yang sesuai untuk menganalisis tingkat partisipasi laki-laki yang sesuai dengan teori dan konsep gender. Adapun penggunaan teori ladder of participation Arnstein (1969) dalam mengukur tingkat partisipasi lakilaki juga perlu kajian lebih lanjut untuk penggunaannya pada skala individu dan rumah tangga.

\section{DAFTAR PUSTAKA}

Advianty SA, Handayeni KDME. 2013. Tingkat partisipasi masyarakat pada pemukiman kumuh Kelurahan Ploso. Jurnal Bina Praja [internet]. [diunduh 2016 Nov 29]; 02(02): 191-196. Tersedia pada:

http://www.ejurnal.its.ac.id/index.php/teknik/article/v iew/3924/1235

Agusni S. 2007. Kekuatan koperasi dalam pemberdayaan perempuan. Jurnal Administrasi Publik [internet]. [diunduh 2016 Okt 14]; 01(15): 1-11. Tersedia pada: http://jurnal.smecda.com/index.php/infokop/article/vi ew/38/35.

Arnold T, Borg B, Bowden R, Cremin P, Daly T, Doorly $\mathrm{M}$, Duffy V, Elvatun K, Elton Z, Glendenning P et al. 2006. 80:20 Development in An Unequal World. Regan C, editor. Wicklow (IE): 80:20 Educating and Acting for a Better World.

Arnstein SR. 1969. A ladder of citizen participation. JAIP [internet]. [diunduh 2016 Nov 29]; 35(04). Tersedia pada: http://lithgow-schmidt.dk/sherryarnstein/ladder-of-citizen-participation.html.

Asmorowati S. 2007. Dampak pemberian kredit mikro untuk perempuan: analisis pengadopsian model grameen bank di Indonesia. Jurnal Masyarakat, Kebudayaan, dan Politik [internet]. [diunduh 2016 Okt 14]; 03(20): 175-190. Tersedia pada: http://journal.unair.ac.id/filerPDF/Dampak\%20Pemb erian $\% 20$ Kredit $\% 20 \mathrm{Mikro} \% 20$ untuk\%20Perempuan. pdf.

Chiuri W. 2008. Men's role in persistent rural poverty: lessons from Kenya. CODESRIA Gender Series Journal [internet]. [diunduh 2016 Sep 20]; 07: 163-
176.

Tersedia

pada:

http://www.codesria.org/spip.php?article1381

Cohen JM dan Uphoff NT. 1979. Participation's Place in Rural Development: Seeking Clarity Through Specificity dalam World Development 8. [diunduh 2016 Des 20]. Tersedia pada: www.researchgate.net/profile/Norman_Uphoff/public ation/

4897194 Participation\%27s Place in Rural Developm ent_Seeking_Clarity_Through_Specificity/links/54e5 $\mathrm{f} 44 \overline{\mathrm{d}} 0 \mathrm{cf} 2 \mathrm{~cd} 2 \mathrm{e} 028 \mathrm{~b} 535 \mathrm{~d}$ ? ev = pub_ext doc_dl\&origin $=$ publication detail\&inViewer=true.

Duadji N. 2013. Partisipasi publik dalam pengambilan keputusan anggaran pendapatan dan belanja daerah (APBD) Provinsi Lampung. Jurnal Bina Praja [internet]. [diunduh 2016 Nov 29]; 05(03): 197-204. Tersedia pada: http://binaprajajournal.com/ojs/index.php/jbp/article/ view/112/107

Elizabeth R. 2007. Pemberdayaan wanita mendukung strategi gender mainstreaming dalam kebijakan pembangunan pertanian di perdesaan. Forum Penelitian Agro Ekonomi [internet]. [diunduh 2016 Okt 14]; 25(02): 126-135. Tersedia pada: http://s3.amazonaws.com/academia.edu.documents/3 5856466/

artikel_pemberdayaan_wanita.pdf?AWSAccessKeyId $=$ AKIAJ56TQJRTWSMTNPEA\&Expires $=14767603$ 48\&Signature $=\mathrm{wk} \% 2 \mathrm{Fw} 1 \mathrm{olFT} 7 \mathrm{jb} 5 \mathrm{GXF112ARMlhR}$ W4\%3D\&response-contentdisposition=inline $\% 3 \mathrm{~B} \% 20$ filename $\% 3$ DPEMBERDAYAAN_WANITA_MENDUKUNG STRATEGI G.pdf.

Handayani T, Sugiarti. 2002. Konsep dan Teknik Penelitian Gender. Malang (ID): UMM Press.

Hapsari DT, Suprijanto, Marijati Sangen, Susilawati. 2012. Faktor-faktor yang mempengaruhi partisipasi masyarakat pada kebun bibit rakyat. J EnviroScienteae [internet]. [diunduh 2017 Mei 21]; 55-61. Tersedia pada:

https://www.google.co.id/url?sa=t\&source=web\&rct= j\&url=http://ppjp.unlam.ac.id/journal/index.php/es/

Hartomo, Aziz A. 1990. Ilmu Sosial Dasar. Jakarta (ID): PT Bumi Aksara.

[IFC] International Finance Corporation. 2016. UKM yang dimiliki wanita di Indonesia: kesempatan emas untuk institusi keuangan lokal [internet]. [diunduh 2017 Mei 31]. Tersedia pada: http://www.ifc.org/wps/wcm/connect/175f322d-ae1f4f8d-9e32-79511247eda a/SME+Indonesia Final Ind.pdf?MOD=AJPERES

Izugbara C, Tikkanen R, Barron K. 2014. Men, masculinity, and community development in Kenyan slums. J Community Development [internet]. [diunduh 2016 Sep 21]; 1-15. Tersedia pada: http://dx.doi.org/10.1080/15575330.2013.868816.

[KPP-PA]. 2012. Kebijakan dan Strategi Peningkatan Produktifitas Ekonomi Perempuan (PPEP). Jakarta 
(ID): Kementerian Pemberdayaan Perempuan dan Perlindungan Anak Republik Indonesia.

[KPP-PA]. 2013. Pembangunan Manusia Berbasis Gender 2013. Jakarta (ID): Kementerian Pemberdayaan Perempuan dan Perlindungan Anak Republik Indonesia.

[KPP-PA]. 2016. Pembangunan Manusia Berbasis Gender 2016. Jakarta (ID): Kementerian Pemberdayaan Perempuan dan Perlindungan Anak Republik Indonesia.

March C, Smyth I, Mukhopadhyay M. 1999. A Guide to Gender-Analysis Framework. Oxford (UK): Oxfam GB.

Martini LKB. 2015. Peranan perempuan pada pembangunan ekonomi dalam perspektif gender di Kabupaten Badung. Juima [internet]. [diunduh 2016 Sep 20]; 05(02): 128-134. Tersedia pada: http://jurnal.unmas.ac.id/index.php/JUIMA/article/vie w/119/96

Mayoux L. 2000. Micro-finance and the empowerment of women: a review of the key issues. $J$ Social Finance [internet]. [diunduh 2017 Feb 14]; No. 23. Tersedia pada:

http://www.ilo.org/employment/Whatwedo/Publicatio ns/ WCMS_117993/lang--en/index.htm.

Mugniesyah SS. 2009. Bahan Ajar Pendidikan Orang Dewasa. [unpublished].

Mustafa M. 2016. Perkembangan jiwa beragama pada masa dewasa. Jurnal Edukasi [internet]. [diunduh 2016 Feb 16]; 02(01): 77-90. Tersedia pada: https:/www.google.co.id/url?sa $=$ t\&rct $=\mathrm{j} \& \mathrm{q}=\&$ esrc $=\mathrm{s}$ \&source $=$ web\&cd $=7 \&$ ved $=0$ ahUKEwjwqcHu05nSA hXHNY8KHflrC10QFghIMAY\&url=http $\% 3 \mathrm{~A} \% 2 \mathrm{~F} \%$ 2Fdownload.portalgaruda.org\%2Farticle.php\%3Farti cle\%3D449044\%26val\%3D7458\%26title\%3DPERK EMBANGAN\%2520JIWA\%2520BERAGAMA\%25 20PADA $\% 2520 \mathrm{MASA} \% 2520 \mathrm{DEWASA} \& u s g=A F Q j$ CNFQHELdvnyLC6Smrw3Z0tYYSWSGtQ\&cad=rja

Nasdian FT. 2014. Pengembangan Masyarakat. Jakarta (ID): Yayasan Pustaka Obor Indonesia.

Pratama C. 2013. Faktor-faktor yang mempengaruhi keberhasilan pemberdayaan perempuan Desa Joho di lereng gunung Wilis. Jurnal Kebijakan dan Manajemen Publik [internet]. [diunduh 2016 Okt 14]; 01(01): 12-19. Tersedia pada: http://journal.unair.ac.id/faktor-faktor-yangmempengaruhi- keberhasilan-pemberdayaan.

Puspitawati H. 2013. Gender dan Keluarga: Konsep dan Realita di Indonesia. Bogor (ID): IPB Press.

Putri CP. 2014. Kesetaraan gender dalam program keluarga berencana (KB) di Dusun Sawahan Desa Sawahan Kecamatan Mojosari Kabupaten Mojokerto. Jurnal Kebidanan [internet]. [diunduh 2016 Sep 20]. Tersedia pada:
Putri RM, Sjamsuddin S, Nurani F. 2013. Pelaksanaan pemberdayaan perempuan dalam mewujudkan keadilan dan kesetaraan jender di bidang ekonomi pada masyarakat jombang (studi peran badan pemberdayaan perempuan dan keluarga berencana kabupaten jombang). Jurnal Administrasi Publik [internet]. [diunduh 2016 Okt 14]; 01(01); 145-152. Tersedia pada: http://administrasipublik.studentjournal.ub.ac.id/inde x.php/jap/article/view/22/20.

Sasanti TE, Sulistiyani N, Suparlan, Rahmat I. 2010. Modul Kewirausahaan dan Perencanaan Usaha (Bisnis Plan). Sasanti TE, editor. Surakarta (ID): Gita Pertiwi.

Sarwono J. 2015. Prosedur-prosedur populer statistik untuk mempermudah riset skripsi. [internet]. [diunduh 2017 Mei 21]. Tersedia pada: www.jonathansarwono.info/?cx=partner-pub$1078747455806481 \% 3 \mathrm{~A} 1 \mathrm{mi} 24 \mathrm{n} 7 \mathrm{rsx} 7 \& \mathrm{cof}=\mathrm{FORID}$ $\% 3 \mathrm{~A} 10 \& \mathrm{ie}=\mathrm{ISO}-8859-1 \& \mathrm{q}=$ Prosedurprosedur+populer\&sa $=$ Search\&siteurl $=$

Saskara IAN, Pudjihardjo, Maskie G, Suman A. 2012. Tinjauan perspektif ekonomi dan nonekonomi perempuan Bali yang bekerja di sektor publik: studi konflik peran. Jurnal Aplikasi Manajemen [internet]. [diunduh 2016 Okt 14]; 10(03): 542-552. Tersedia pada:

http://jurnaljam.ub.ac.id/index.php/jam/article/view/4 46.

Setiyono A, Novianti S. 2015. Faktor determinan partisipasi pria dalam vasektomi. Jurnal Kesehatan Komunitas Indonesia [internet]. [diunduh 2016 Sep 20]; 11(02): 1162-1170. Tersedia pada: http://lppm.unsil.ac.id/files/2016/03/FAKTORDETERMINAN-PARTISIPASI-PRIA-DALAMVASEKTOMI-Andik-Setiyono-dan-SitiNovianti.pdf.

Singarimbun M, Mantra IB, Effendi S, Ancok D, Manning C, Kasto, Hagul P, Singarimbun I, Sucipto T, Ismulyana et al. 2014. Metode Penelitian Survey. Effendi S, Tukiran, editor. Jakarta (ID): LP3ES.

Supeni RE, Sari MI. 2011. Upaya pemberdayaan ekonomi perempuan melalui pengembangan manajemen usaha kecil (studi deskriptif pada kegiatan usaha kecil ibuibu Desa Wirolegi Kabupaten Jember, dampingan pusat studi wanita UM Jember). [internet]. [diunduh 2017 Feb 14]. Tersedia pada: http://jurnal.unimus.ac.id/index.php/psn12012010/arti cle/download/411/460

Utomo BS, Lubis DP, Wahyuni ES, Soetarto E, Nasdian FT, Agusta I, Kolopaking LM, Sunito MA, Sitorus MTF, Prasodjo NW et al. 2015. Sosiologi Umum. Nasdian FT, editor. Jakarta (ID): Yayasan Pustaka Obor Indonesia http://repository.poltekkesmajapahit.ac. id/index.php/PUB-KEB/article/view/179/149. 